\title{
Pengaruh Pemberian Terapi Aktivitas Kelompok Sosialisasi Terhadap Perubahan Perilaku Klien Isolasi Sosial
}

\author{
Surya Efendia ${ }^{a}$, Atih Rahayuningsih ${ }^{b}$, Wan Muharyati ${ }^{c}$

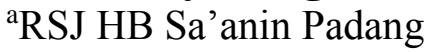 \\ ${ }^{\mathrm{b}}$ Keperawatan Universitas Andalas \\ 'Perawat RSJ HB Sa'anin Padang
}

\begin{abstract}
This study aims to determine the Effect of Activity Group Therapy: Socialization (AGTS) to Client Behavior Change Social Isolation in Gelatik Room Prof. HB Sa'anin Mental Hospital Padang. This study used quasi experiment design without a control group with the approach one group pretest and posttest design. Objects in this study is the client's social isolation. Sampling was purposive sampling with a sample of 10 people. Instruments used in the form of sheets of observation and interview guides. Clients of social isolation pretest conducted before given AGTS, then do posttest. The average value of 31.5 pretest and posttest mean value of 40.1. This shows a decline in social isolation behavior after being given the AGTS. Data were analyzed using Two Different Tests Mean Dependent (Paired Samples) with 95\% degree of confidence. The results of statistical tests obtained $p=0.00(p<0.05)$. This suggests there is a significant influence on the administration AGTS to changes in client behavior of social isolation. Expected to hospital nurses to be able to improve the implementation of AGTS with respect to indications that the client can participate in the activities of the AGTS. Then the researchers next to be examined by using qualitative techniques.
\end{abstract}

Key words: social isolation, behaviour changes, group activity therapy

\begin{abstract}
Abstrak: Penelitian ini bertujuan untuk mengetahui pengaruh pemberian terapi aktivitas kelompok sosialisasi terhadap Perubahan Perilaku Klien Isolasi Sosial di Ruang Gelatik RS Jiwa Prof HB Sa'anin Padang. Penelitian ini menggunakan desain quasi experiment tanpa kelompok kontrol dengan pendekatan one group pretest and posttest design. Sampel dalam penelitian ini adalah klien isolasi sosial yang diambil secara purposive sampling berjumlah 10 orang. Instrumen yang digunakan berupa lembar observasi dan pedoman wawancara.Nilai rata-rata pretest 31,5 dan posttest 40,1. Data diuji dengan Uji Beda Dua Mean Dependen (Paired Sampel) dengan derajat kepercayaan $95 \%$. Hasil uji statistik didapatkan $p=0,00(p<0,05)$. Hal ini menunjukkan terdapat pengaruh yang bermakna pada pemberian TAKS terhadap perubahan perilaku klien isolasi sosial. Diharapkan kepada perawat rumah sakit untuk dapat meningkatkan pelaksanaan TAKS dengan memperhatikan indikasi klien yang bisa diikutsertakan dalam kegiatan TAKS. Kemudian kepada peneliti selanjutnya diharapkan untuk dapat melanjutkan penelitian ini dengan menggunakan teknik kualitatif.
\end{abstract}

Kata kunci: isolasi sosial, perubahan perilaku, terapi aktifitas kelompok

Sehat menurut WHO adalah keadaan yang sempurna baik fisik, mental maupun sosial, tidak hanya terbebas dari penyakit, kelemahan atau cacat (Notosoedirjo, 2002).
Dalam definisi tersebut jelas bahwa sehat bukan sekedar terbebas dari penyakit atau cacat. Orang yang tidak berpenyakit pun belum tentu dikatakan sehat. Seseorang 
semestinya dalam keadaan yang sempurna baik fisik, mental maupun sosial. Dalam perkembangan dan pembangunan dunia akhirakhir ini yang ditandai dengan modernisasi, industrialisasi dan globalisasi, akan membawa banyak perubahan dalam kehidupan yang bisa menjadi stressor bagi seseorang. Dengan tingginya stressor itu diperkirakan gangguan jiwa akan semakin meningkat (Setiaji, 2002).

Salah satu bentuk gangguan jiwa yang paling banyak terdapat di seluruh dunia adalah gangguan jiwa skizofrenia. Prevalensi skizofrenia di dunia adalah 0,1 per mil dengan tanpa memandang perbedaan status sosial atau budaya (Varcarolis and Halter 2010). Sedangkan hasil riset dasar kesehatan nasional tahun 2007 menyebutkan bahwa sebanyak 0,46 per mil masyarakat Indonesia mengalami gangguan jiwa berat. Mereka adalah yang diketahui mengidap skizofrenia dan mengalami gangguan psikotik berat (Depkes RI, 2007).

Skizofrenia adalah suatu gangguan jiwa berat yang ditandai dengan penurunan atau ketidakmampuan berkomunikasi, gangguan realitas (halusinasi atau waham), afek yang tidak wajar atau tumpul, gangguan kognitif (tidak mampu berpikir abstrak) serta mengalami kesukaran melakukan aktivitas sehari-hari. Salah satu gejala negatif skizofrenia adalah menarik diri dari pergaulan sosial (isolasi sosial). Isolasi sosial adalah keadaan dimana seorang individu mengalami penurunan atau bahkan sama sekali tidak mampu berinteraksi dengan orang lain di sekitarnya. Pasien mungkin merasa ditolak, tidak diterima, kesepian dan tidak mampu membina hubungan yang berarti dengan orang lain (Keliat et al, 2005).

Terjadinya gangguan ini dipengaruhi oleh faktor predisposisi diantaranya perkembangan dan sosial budaya. Kegagalan dapat mengakibatkan individu tidak percaya pada diri, tidak percaya pada orang lain, ragu, takut salah, pesimis, putus asa terhadap orang lain, tidak mampu merumuskan keinginan, dan merasa tertekan. Keadaan ini dapat menimbulkan perilaku tidak ingin berkomunikasi dengan orang lain, lebih menyukai berdiam diri, menghindar dari orang lain, dan kegiatan sehari-hari terabaikan (Kusumawati dan Hartono, 2010). Menurut Stuart and Sundeen, (2006) Individu dalam situasi seperti ini harus diarahkan pada respon perilaku dan interaksi sosial yang optimal melalui asuhan keperawatan yang komprehensif dan terus menerus disertai dengan terapi-terapi modalitas seperti Terapi Aktivitas Kelompok (TAK), bahkan TAK Sosialisasi memberikan modalitas terapeutik yang lebih besar daripada hubungan terapeutik antara dua orang yaitu perawat dan klien.

TAK adalah terapi modalitas yang dilakukan perawat kepada sekelompok klien yang mempunyai masalah keperawatan yang sama. Aktivitas yang digunakan sebagai terapi, dan kelompok digunakan sebagai target asuhan. Di dalam kelompok terjadi dinamika interaksi yang saling bergantung, saling membutuhkan dan menjadi laboratorium tempat klien berlatih perilaku baru yang adaptif untuk memperbaiki perilaku lama yang maladaptif. Stuart and Sundeen (2006) menambahkan bahwa TAK dilakukan untuk meningkatkan kematangan emosional dan psikologis pada klien yang mengidap gangguan jiwa pada waktu yang lama. TAK dapat menstimulus interaksi diantara anggota yang berfokus pada tujuan kelompok. TAK Sosialisasi juga membantu klien berinteraksi/berorientasi dengan orang lain.

Terapi Aktivitas Kelompok : Sosialisasi (TAKS) merupakan suatu rangkaian kegiatan yang sangat penting dilakukan untuk membantu dan memfasilitasi klien isolasi sosial untuk mampu bersosialisasi secara bertahap melalui tujuh sesi untuk melatih kemampuan sosialisasi klien. Ketujuh sesi tersebut diarahkan pada tujuan khusus TAKS, yaitu : kemampuan memperkenalkan diri, kemampuan 
berkenalan, kemampuan bercakap-cakap, kemampuan menyampaikan dan membicarakan topik tertentu, kemampuan menyampaikan dan membicarakan masalah pribadi, kemampuan bekerja sama, kemampuan menyampaikan pendapat tentang manfaat kegiatan TAKS yang telah dilakukan. Langkah-langkah kegiatan yang dilakukan dalam TAKS yaitu tahap persiapan, orientasi, tahap kerja dan tahap terminasi dengan menggunakan metode dinamika kelompok, diskusi atau tanya jawab serta bermain peran atau stimulasi.

Penelitian yang dilakukan oleh Setya, $\mathrm{T}$ (2009) didapatkan adanya pengaruh TAKS terhadap kemampuan berinteraksi pada klien isolasi sosial di Rumah Sakit Jiwa Pusat Dr. Soeharto Heerdjan Jakarta. Sedangkan penelitian Joko (2009) di Rumah Sakit Jiwa Surakarta menyatakan bahwa ada pengaruh yang signifikan pelaksanaan TAKS sesi satu dan sesi dua terhadap perubahan perilaku menarik diri.

Berdasarkan data laporan masingmasing ruang rawat inap RS. Jiwa Prof. HB. Sa'anin Padang dalam enam bulan terakhir (dari bulan Maret 2011 sampai Agustus 2011), diketahui bahwa klien dengan masalah isolasi sosial terbanyak terdapat di ruang Gelatik yaitu sebanyak 64 orang dari 352 orang $(18,1 \%)$. Sedangkan di ruangan Merpati sebanyak 54 orang dari 382 orang $(14,1 \%)$, ruangan Melati sebanyak 45 orang dari 331 orang $(13,5 \%)$, ruangan Cenderawasih 34 orang dari 462 orang $(7,3$ $\%)$, ruangan Flamboyan 19 orang dari 288 orang $(6,6 \%)$, dan ruangan Anggrek sebanyak 4 orang dari 86 orang $(4,7 \%)$.

RS. Jiwa Prof. HB. Sa'anin Padang merupakan sebuah Rumah Sakit Jiwa tipe A yang telah menerapkan Terapi Aktivitas Kelompok yaitu dengan dibentuknya ruang MPKP, dimana salah satu programnya adalah pelaksanaan TAK. Berdasarkan pengalaman peneliti secara langsung selama bekerja di RS Jiwa Prof. HB. Sa'anin Padang diketahui bahwa semua ruang rawat inap di RS. Jiwa Prof. HB. Sa'anin Padang khususnya ruang Gelatik telah melaksanakan TAK sebagai bagian dari kegiatan perawatan pasien yang dilaksanakan setiap hari yang salah satunya adalah TAKS. TAKS dilakukan berurutan dari sesi 1 sampai sesi 7 yang dilaksanakan oleh perawat ruangan dan mahasiswa yang sedang melaksanakan praktik klinik di RS. Jiwa Prof. HB. Sa'anin Padang. Perawat melaksanakannya sesuai dengan prosedur yang ada pada buku panduan, tapi belum sepenuhnya memperhatikan indikasi untuk pasien yang sudah bisa diikutsertakan dalam kegiatan ini, seperti masih ada klien yang belum bisa melakukan interaksi interpersonal dan berespon sesuai dengan stimulus juga diikutsertakan. Selain itu, klien yang tidak ada kemajuan setelah dirawat secara individu juga diikutsertakan dalam kegiatan TAKS, padahal klien seperti ini belum bisa diikutsertakan karena tidak akan memberi dampak walaupun dilibatkan dalam kegiatan TAKS.

Hasil observasi pada tanggal 16 Oktober 2011 pada sepuluh orang klien dengan masalah keperawatan isolasi sosial yang telah diberikan TAKS sesi 1 sampai sesi 7 di ruang Gelatik RS Jiwa Prof. HB. Sa'anin Padang, ditemukan tujuh orang klien masih suka menyendiri, jarang berbincang-bincang dengan pasien yang lain, terlihat tidak semangat, afek tumpul, kontak mata kurang dan lebih sering menunduk, sedangkan tiga orang pasien yang sudah mulai mau berinteraksi dengan pasien yang lain kadangkadang masih sering tampak melamun.

Data di atas menunjukkan bahwa pasien yang telah mendapat TAKS sebagian besar masih menunjukkan perilaku isolasi sosial, seperti masih suka menyendiri, jarang berbincangbincang dengan pasien yang lain, tampak tidak bersemangat, afek tumpul, kontak mata kurang dan lebih sering menunduk. Padahal secara teoritis TAKS dapat membantu pasien untuk berinteraksi/bersosialisasi dengan orang lain. 
Penelitian ini bertujuan untuk mengetahui bagaimana pengaruh pemberian terapi aktivitas kelompok sosialisasi terhadap perubahan perilaku klien isolasi sosial di Ruang Gelatik RS Jiwa Prof HB Sa'anin Padang Tahun 2011.

\section{METODE}

Penelitian ini menggunakan desain quasi eksperiment tanpa kelompok kontrol dengan pendekatan one group pretest and posttest design (Nursalam, 2008). Dalam rancangan ini kelompok subjek dilakukan pretest terlebih dahulu. Populasi dalam penelitian ini adalah jumlah pasien isolasi sosial yang dirawat di ruang Gelatik RS. Jiwa Prof. HB. Sa'anin Padang dalam 6 bulan terakhir (dari bulan Maret 2011 sampai bulan Agustus 2011), yaitu berjumlah : 64 orang dengan rata-rata perbulan 11 orang. teknik pengambilan sampel yang digunakan peneliti adalah purposive sampling, yaitu penelitian yang didasarkan pada suatu pertimbangan tertentu yang dibuat oleh peneliti sendiri berdasarkan ciri atau sifat-sifat populasi yang sudah diketahui sebelumnya. Jumlah sampel yang digunakan dalam penelitian ini adalah 10 orang yang didasarkan pada jumlah anggota kelompok kecil menurut Stuart dan Laraia (2006), yaitu 7-10 orang. Untuk menetapkan sampel maka digunakan kriteria inkulusi dan kriteria eksklusi. Kriteria inklusi adalah karakteristik umum subjek penelitian dari suatu populasi, suatu target dan terjangkau akan diteliti (Nursalam, 2008).

Adapun kriteria inklusi penelitian ini adalah :

a. Klien isolasi sosial yang sudah mendapat asuhan keperawatan untuk masalah isolasi sosial.

b. Klien isolasi sosial yang telah mulai melakukan interaksi interpersonal.

c. Klien isolasi sosial yang telah mulai berespon sesuai dengan stimulus.

d. Klien isolasi sosial yang bersedia dijadikan responden.

Penelitian ini dilakukan di Ruang Gelatik RS Jiwa Prof HB Sa'anin Padang dari bulan Agustus sampai Desember 2011.

\section{HASIL DAN PEMBAHASAN}

Hasil pengambilan data pada klien isolasi sosial di Ruang Gelatik RS. Jiwa Prof. HB. Sa'anin Padang selama 10 hari mulai dari tanggal 4 sampai 13 Desember 2011 dengan jumlah responden 10 orang didapatkan data sebagai berikut :

Tabel 1. Distribusi Frekuensi Responden Berdasarkan Karakteristik Umur, Jenis Kelamin, Pekerjaan dan Pendidikan di Ruang Gelatik RS Jiwa Prof. HB. Sa'anin Padang Tahun 2011

\begin{tabular}{llccc}
\hline No & Karakteristik & Kriteria & Frekuensi & Persentase \\
\hline 1. & Umur & $18-25$ & 4 & 40 \\
& Cameron (1969) & (Dewasa Muda Awal) & & 60 \\
& & $>25-40$ & 6 & \\
& Total & (Dewasa Muda Akhir) & & 100 \\
& & & 10 & 100 \\
2. & Jenis Kelamin & Laki-Laki & 10 & 0 \\
& Total & Perempuan & 0 & 100 \\
& & 10 & 40 \\
3. & Pekerjaan & Bekerja & 4 & 60 \\
& & Tidak Bekerja & 6 & 100
\end{tabular}


4. Pendidikan

$\mathrm{SD}$

$3 \quad 30$

SMP/Sederajat

$5 \quad 50$

$\begin{array}{lll}\text { SMA/Sederajat } & 2 & 20\end{array}$

Perguruan Tinggi

$0 \quad 0$

Total

10

100

Tabel di atas memperlihatkan bahwa lebih dari separuh $(60 \%)$ responden berumur $>25-40$, semua responden $(100 \%)$ berjenis kelamin laki-laki, lebih dari separuh $(60 \%)$ responden tidak bekerja, lebih banyak (50\%) responden berpendidikan SMP.

Tabel 2. Rerata perbahan perilaku isolasi sosial sebelum dan sesudah terapi aktivitas kelompok sosialisasi di Ruang Gelatik RS Jiwa Prof. HB. Sa'anin Padang Tahun 2011

\begin{tabular}{|c|c|c|c|}
\hline $\begin{array}{c}\text { No. } \\
\text { Responden }\end{array}$ & $\begin{array}{c}\text { Sebelum Perlakuan } \\
\text { (Pretest) }\end{array}$ & $\begin{array}{c}\text { Setelah Perlakuan } \\
\text { (Posttest) }\end{array}$ & Kategor \\
\hline 1 & 30 & 41 & $\begin{array}{ll}\uparrow & 11\end{array}$ \\
\hline 2 & 27 & 37 & $\uparrow \quad 10$ \\
\hline 3 & 30 & 39 & $\uparrow \quad 9$ \\
\hline 4 & 33 & 43 & $\uparrow 10$ \\
\hline 5 & 33 & 41 & $\uparrow$ \\
\hline 6 & 30 & 37 & $\uparrow$ \\
\hline 7 & 34 & 42 & $\uparrow 8$ \\
\hline 8 & 35 & 41 & 46 \\
\hline 9 & 31 & 39 & ^ 8 \\
\hline 10 & 32 & 41 & $\uparrow$ \\
\hline $\bar{X}$ & 31.5 & 40,1 & \\
\hline
\end{tabular}

Tabel 2. di atas memperlihatkan bahwa semua responden $(100 \%)$ mengalami perubahan perilaku isolasi sosial, yang berarti bahwa terjadi penurunan perilaku isolasi sosial dari sebelum dan sesudah perlakuan dalam rentang 6 sampai 11 dengan nilai ratarata pretest 31,5 dan nilai rata-rata posttest 40,1. Rata-rata perilaku isolasi sosial responden pada saat pretest dan posttest didapatkan perbedaan nilai sebesar 8,6, artinya perilaku isolasi sosial klien menurun sebesar 15,3\% setelah diberikan TAKS selama 7 sesi. Adapun klien yang mengalami rentang perubahan nilai 6 sampai 8 adalah 5 orang $(50 \%)$, sedangkan yang mengalami rentang perubahan nilai 9 sampai 11 adalah 5 orang $(50 \%)$. Penelitian ini sesuai dengan penelitian yang dilakukan oleh Joko (2009) di Rumah Sakit Jiwa Surakarta yang menyatakan bahwa ada pengaruh yang signifikan pelaksanaan TAKS sesi satu dan sesi dua terhadap perubahan perilaku menarik diri dengan perbedaan nilai antara pretest dan posttest yaitu sebesar 0,34 .

Salah satu gejala negatif skizofrenia adalah menarik diri dari pergaulan sosial (isolasi sosial). Isolasi sosial adalah keadaan dimana seorang individu mengalami penurunan atau bahkan sama sekali tidak mampu berinteraksi dengan orang lain di sekitarnya. Pasien mungkin merasa ditolak, tidak diterima, kesepian dan tidak mampu membina hubungan yang berarti dengan orang lain (Keliat et al, 2005). 
Penelitian ini menunjukkan bahwa semua responden berada dalam rentang usia dewasa muda. Hal ini sesuai dengan pendapat Natsir dan Muhith (2010) yang menyatakan bahwa skizofrenia ditemukan 7 per mil orang dewasa dan terbanyak usia 15-35 tahun. Sedangkan dilihat dari karakteristik responden berdasarkan pekerjaan, didapatkan lebih dari separoh $(60 \%)$ responden tidak bekerja. Menurut Prayitno, E (2006), bekerja merupakan salah satu dimensi kehidupan orang dewasa awal yang sangat penting. Mereka bekerja dengan berbagai alasan, seperti untuk mendapatkan kepuasan pribadi, penghasilan, dan status sosial. Bagi kalangan ekonomi lemah, bekerja untuk mendapatkan penghasilan. Bagi kalangan ekonomi tinggi, tujuan bekerja adalah untuk mendapatkan kepuasan dan status. McGhie, Andrew (1996) menyatakan bahwa alasan yang paling lazim dari simptom neurotik yang diberikan pasien dewasa yang menjalani rawat jalan di bagian psikiatri adalah bekerja terlalu keras atau stress yang diberikan dengan pekerjaan. Bila kita tidak mampu mencapai kepuasan atau menemukan makna dari pekerjaan kita, dalam batas tertentu kita gagal dalam mengekspresikan diri yang mengakibatkan rasa tidak puas dan kecewa.

McGhie, Andrew

menambahkan bahwa seseorang yang tidak mampu merampungkan volume pekerjaan yang sama, atau apabila ia tidak mampu menangani atau tidak memiliki pekerjaan domestik rutin, dalam suasana hati yang demikian seseorang merasa sedih, pesimis terhadap masa depan dan ia mungkin terlalu merisaukan kesehatannya secara tidak wajar. Minatnya semakin berkurang dan perhatiannya tidak lagi dapat terpusat pada kegiatan-kegiatan yang semula digemarinya. Ia merasa dunia sebagai tempat yang menyedihkan dan tidak dapat membayangkan perbaikan-perbaikan di kemudian hari atau mengingat saat-saat dimana ia merasa gembira dan puas. Selera makannya berkurang dan berat badannya mulai menurun. Tidurnya hampir selalu terganggu dan keluhan yang paling sering adalah terbangun dini hari dan tidak dapat tidur sesudahnya. Dengan berkembangnya depresi seseorang menjadi lebih lamban, merasa sedih dan mungkin terlalu dihantui rasa bersalah dan tidak berguna.

Terjadinya gangguan dalam berhubungan dengan orang lain (isolasi sosial) juga dapat dipengaruhi oleh jenis kelamin. Dalam penelitian ini didapatkan semua $(100 \%)$ responden berjenis kelamin laki-laki. Gillian (1982) dalam Abraham dan Shanley (1997) menyatakan bahwa bagi perempuan adanya kepentingan dan hubungan pengasuhan dapat membuat mereka mengembangkan keterampilan yang bersifat hirarki. Laki-laki di sisi lain tidak mengalami kesulitan pada persaingan tetapi bermasalah dalam membuat hubungan dengan orang lain yang berarti bertentangan dengan kemandiriannya. Selain itu, Maccoby dan Jackson (1974) dalam Abraham dan Shanley (1997) menyatakan bahwa perempuan mempunyai kemampuan verbal dan bahasa lebih baik dibandingkan dengan laki-laki.

Pernyataan di atas menjelaskan bahwa seorang laki-laki memiliki masalah dalam membuat hubungan dengan orang lain, hal ini berarti laki-laki cenderung mengisolasikan dirinya dari pergaulan sosial (isolasi sosial). Selain itu, Laki-laki juga memiliki kemampuan verbal dan bahasa yang kurang dari perempuan, sehingga laki-laki cenderung tertutup dan memendam sendiri setiap masalah dan stessor psikologis yang mereka hadapi. Kondisi ini jika berlangsung lama dengan tanpa ada mekanisme koping yang konstruktif, maka kecenderungan ia jatuh ke dalam gangguan jiwa akan lebih tinggi.

Dilihat dari hasil observasi pada saat pretest yang dapat dilihat pada master tabel, hal yang paling banyak dilakukan oleh klien adalah menyendiri dalam ruangan dengan total nilai nilai 17 , tidak berkomunikasi 
dengan total nilai 20, suka melamun dengan total nilai 19 dan menghindar dari orang lain dengan total nilai 19. Setelah diberikan TAKS, hal tersebut mengalami penurunan dengan nilai perubahan sebagai berikut : menyendiri dalam ruangan 10, tidak berkomunikasi 8 , suka melamun 9, dan menghindar dari orang lain 8. Sedangkan dilihat dari pedoman wawancara, hal yang paling banyak dirasakan klien pada saat pretest adalah merasa kesepian dengan total nilai 19 , tidak percaya atau merasa tidak aman berada dengan orang lain dengan total nilai 20 dan merasa bosan dan lambat menghabiskan waktu dengan total nilai 19. Setelah diberikan TAKS, hal tersebut mengalami perubahan dengan nilai perubahan sebagai berikut : merasa kesepian 9, tidak percaya atau merasa tidak aman berada dengan orang lain 7 dan merasa bosan dan lambat menghabiskan waktu 4.

Perubahan ini sesuai dengan pernyataan Stuart and Sundeen (2006) yang menyatakan bahwa TAKS dilakukan untuk meningkatkan kematangan emosional dan psikologis pada klien yang mengidap gangguan jiwa pada waktu yang lama. TAKS dapat menstimulus interaksi diantara anggota yang berfokus pada tujuan kelompok. TAKS juga membantu klien berinteraksi/berorientasi dengan orang lain.

Menurut Niven, (2000) Keberhasilan pasien dalam TAK dimungkinkan karena telah terbentuknya rasa percaya antara anggota kelompok, dimana rasa saling percaya (trust) antara anggota akan memungkinkan pasien untuk dapat bekerja sama. Rasa saling percaya, saling menerima dalam norma kelompok akan meningkatkan rasa kebersamaan antar anggota. Dimana kekuasaan dan pengaruh masing-masing anggota kelompok sangat menentukan dalam pencapaian tujuan dari suatu TAK. Selain itu juga dapat dipengaruhi oleh peran terapis dalam memberikan motivasi kepada responden agar terlibat dalam diskusi.
Dalam penelitian ini masih terdapat separuh $(50 \%)$ responden yang mengalami penurunan perilaku isolasi sosial dalam rentang 6 sampai 8. Walaupun tidak ada yang mengalami penurunan nilai atau peningkatan perilaku isolasi sosial dalam penelitian ini, perubahan skor yang sedikit dalam penelitian ini dapat terjadi karena penurunan konsentrasi dan juga sikap responden selama kegiatan TAKS. Hal ini dapat diihat dari hasil evaluasi TAKS yang menunjukkan masih adanya responden yang tidak ada/kurang kontak mata, menggunakan bahasa tubuh yang tidak sesuai dan minta izin ke kamar mandi, minum ataupun melakukan kegiatan lain di luar ruangan TAK pada setiap sesi selama pelaksanaan TAKS. Menurut Depkes, (2000) keadaan ini dipengaruhi oleh faktor internal yaitu faktor sosiopsikologis seperti sikap, kebiasaan dan kemauan dapat mempengaruhi apa yang kita perhatikan dan faktor eksternal yang terdiri dari intensitas stimulus sehingga perhatian akan tertuju atau terfokus pada stimulus yang menonjol serta dapat juga dipengaruhi oleh faktor lingkungan, dimana lingkungan yang bising, warna yang mencolok akan mempengaruhi konsentrasi anggota kelompok dalam melakukan TAK.

Selain itu, keadaan tersebut di atas juga dapat dipengaruhi oleh tingkat pendidikan responden, dimana dalam penelitian ini didapatkan lebih banyak (50\%) responden dengan tingkat pendidikan SMP/Sederajat. Menurut Purwanto, H (1999), inti dari kegiatan pendidikan adalah proses belajar mengajar. Hasil dari proses belajar mengajar adalah seperangkat perubahan perilaku. Dengan demikian, pendidikan sangat besar pengaruhnya terhadap perilaku seseorang. Seseorang yang berpendidikan tinggi akan berbeda perilakunya dengan orang yang berpendidikan rendah.

Seseorang yang memiliki tingkat pendidikan yang tinggi akan relatif mudah memahami setiap terapi yang diberikan dalam kegiatan TAKS. Sehingga akan menghasilkan 
penurunan perilaku isolasi sosial yang cepat. Sedangkan tingkat pendidikan yang rendah membuat proses terapi dalam TAKS menjadi terhambat sehingga penurunan perilaku isolasi sosial klien juga akan ikut terhambat.

Tabel 3. Pengaruh Pemberian Terapi Aktivitas Kelompok : Sosialisasi (TAKS) terhadap Perubahan Perilaku Klien Isolasi Sosial di Ruang Gelatik RS Jiwa Prof. HB. Sa'anin Padang Tahun 2011

\begin{tabular}{|c|c|c|c|c|c|c|}
\hline \multirow[t]{2}{*}{ Variabel } & \multirow[t]{2}{*}{ Mean } & \multirow[t]{2}{*}{ SD } & \multicolumn{2}{|c|}{ CI $95 \%$} & \multirow[t]{2}{*}{$\mathbf{t}$} & \multirow{2}{*}{$\mathbf{p}$} \\
\hline & & & Lower & Upper & & \\
\hline Pretest & 31,50 & 2,369 & & & & \\
\hline Perilaku Isolasi Sosial & & & $-9,677$ & $-7,523$ & $-18,064$ & 0,00 \\
\hline $\begin{array}{l}\text { Posttest } \\
\text { Perilaku Isolasi Sosial }\end{array}$ & 40,10 & 2,025 & & & & \\
\hline
\end{tabular}

Hasil uji statistik dengan menggunakan Uji Beda Dua Mean Dependen (Paired Sampel) didapatkan rata-rata perilaku isolasi sosial sebelum pemberian TAKS adalah 31,50 dengan standar deviasi 2,369. Sedangkan ratarata perilaku isolasi sosial setelah pemberian TAKS adalah 40,10 dengan standar deviasi 2,025 . Hasil uji statistik ini didapatkan nilai $p$ $=0,00 \quad(\mathrm{p}<0,05)$, maka dapat disimpulkan terdapat pengaruh yang bermakna pada pemberian TAKS terhadap perubahan perilaku klien isolasi sosial. Dengan demikian Ho ditolak.

Penelitian ini juga sejalan dengan penelitian Joko (2009) di Rumah Sakit Jiwa Surakarta dengan nilai $\mathrm{p}=0,00(\mathrm{p}<0,05)$. Namun, pada penelitian yang dilakukan oleh Joko (2009) hanya melaksanakan TAKS dalam 2 sesi saja, yaitu sesi 1 dan sesi 2. Padahal menurut Keliat dan Akemat (2004), rangkaian kegiatan dalam TAKS terdiri dari tujuh sesi. Sedangkan dalam penelitian ini, peneliti melaksanakan semua sesi dalam TAKS, yaitu dari 1 sampai sesi 7 .

Menurut Niven (2000) TAK sangat efektif dilakukan pada pasien gangguan jiwa karena memiliki beberapa keuntungan yang akan diperoleh pasien, meliputi dukungan moral, pendidikan, meningkatkan kemampuan pemecahan masalah dan meningkatkan hubungan interpersonal.
Dilihat dari tujuan terapeutik, TAKS mempunyai tujuan untuk memfasilitasi proses interaksi, meningkatkan sosialisasi, meningkatkan kemampuan klien memberi respon terhadap realita, mengenali cara baru dalam mengatasi masalah, meningkatkan identitas diri, menyalurkan emosi secara konstruktif dan meningkatkan kemampuan ekspresi diri. Sedangkan dilihat dari tujuan rehabilitasi, TAKS bertujuan untuk meningkatkan keterampilan ekspresi diri, meningkatkan kemampuan berempati, meningkatkan kemampuan berhubungan sosial, meningkatkan kemampuan pemecahan masalah dan meningkatkan kepercayaan diri (Depkes RI, 2000).

Pemberian TAKS pada responden dalam penelitian ini dilakukan secara bertahap dan dilaksanakan dalam tujuh sesi yang dilaksanakan sesuai dengan prosedur yang ada dalam buku panduan dan responden yang diikutsertakan dalam kegiatan ini memenuhi indikasi pasien TAKS. Adapun indikasinya adalah klien isolasi sosial yang telah mulai melakukan interaksi interpersonal, dan telah mulai berespon sesuai dengan stimulus.

Pelaksanaan TAKS di RS Jiwa Prof. HB. Sa'anin Padang telah sesuai dengan prosedur yang ada dalam buku panduan, tapi perawat belum sepenuhnya memperhatikan indikasi untuk pasien yang sudah bisa diikutsertakan dalam kegiatan ini, seperti 
masih ada klien yang belum bisa melakukan interaksi interpersonal dan berespon sesuai dengan stimulus juga diikutsertakan. Selain itu, klien yang tidak ada kemajuan setelah dirawat secara individu juga diikutsertakan dalam kegiatan TAKS. Hal ini berbeda dengan yang dilakukan dalam penelitian ini, dimana peneliti melaksanakan TAKS sesuai dengan buku panduan dan memperhatikan indikasi pasien yang bisa diikutsertakan dalam TAKS. Sehingga terapi yang diberikan dapat memberikan perubahan yang bermakna terhadap perubahan perilaku klien isolasi sosial.

Dilihat dari hasil evaluasi masingmasing sesi pada saat pelaksanaan TAKS, ditemukan responden yang mengalami penurunan kemampuan dari sesi sebelumnya. Seperti yang dialami oleh responden 2 dan responden 9. pada pelaksanaan TAKS sesi 4, responden 2 mampu menyampaikan topik secara spontan, memilih topik secara spontan dan memberi pendapat secara spontan. Namun pada pelaksanaan TAKS sesi 5 dan sesi 6, hal tersebut mengalami penurunan. Begitu juga dengan responden 9, pada saat pelaksanaan TAKS sesi 4 responden mampu menyampaikan topik dengan jelas, menyampaikan topik secara spontan dan menjawab dan memberi secara spontan. Namun pada sesi 5, terjadi penurunan kemampuan dalam menyampaikan topik dengan jelas dan menyampaikan topik secara spontan. Sedangkan pada sesi 6 terjadi penurunan kemampuan dalam menjawab dan memberi secara spontan. Oleh karena itu, perlu diadakan penelitian lebih lanjut mengenai TAKS dengan menggunakan teknik kualitatif agar masing-masing responden dapat lebih mengeksplorasikan perasaan dan pikirannya sehingga dapat diketahui penyebab terjadinya penurunan kemampuan responden pada masing-masing sesi pelaksanaan TAKS.

\section{KESIMPULAN DAN SARAN}

Penelitian ini menyimpulkan bahwa seluruh responden mengalami penurunan perilaku isolasi sosial setelah diberikan TAKS. Selain itu, terdapat pengaruh yang bermakna pada pemberian TAKS terhadap perubahan perilaku klien isolasi sosial.

Disarankan kepada perawat di RS. Jiwa Prof. HB. Sa'anin Padang untuk dapat meningkatkan pelaksanaan TAKS dengan memperhatikan indikasi klien yang sudah bisa diikutsertakan dalam TAKS. Kepada peneiti selanjutnya untuk dapat melakukan penelitian lebih lanjut tentang TAKS dengan menggunakan teknik kualitatif untuk klien yang masih ditemukan penurunan kemampuan dalam masing-masing sesi pada kegiatan TAKS agar klien tersebut dapat mengeksplorasikan perasaan dan pikirannya sehingga dapat diketahui penyebab penurunan kemampuan tersebut.

\section{DAFTAR PUSTAKA}

Abraham \& Shanley. (1997). Psikologi sosial untuk perawat. Jakarta: EGC.

Departemen Kesehatan Republik Indonesia. (2000). Keperawatan jiwa, teori dan tindakan keperawatan. Jakarta.

Departemen Kesehatan Republik Indonesia. (2007). Laporan hasil riset kesehatan dasar. Jakarta.

Isaacs, A. (2004). Keperawatan Kesehatan Jiwa dan Psikiatri. Jakarta: EGC.

Joko. (2009). Pengaruh pelaksanaan terapi aktivitas kelompok sosialisasi sesi 1 dan sesi 2 terhadap perubahan perilaku menarik diri klien di Ruang Abimayu, Ruang Maespati dan Ruang Pringgodani di RSJ Daerah Surakarta. Diakses Tanggal 4 Juni 2011 dari http://www.scribd/doc/32713247/proposal -terapi-aktivitas-kelompok-sosialisasi

Keliat, B. A. (2005a). Keperawatan jiwa TAK. Jakarta: EGC. 
Keliat, B.A. (2005b). Modul basic course community mental health nursing. Jakarta : FIK UI.

Kusumawati, F \& Hartono, Y. (2010). Buku ajar keperawatan jiwa. Malang: Salemba Medika.

McGhie, A. (1996). Penerapan psikologi dalam perawatan. Yogyakarta: Yayasan Essentia Medica.

Natsir \& Muhith. (2010). Dasar-dasar keperawatan jiwa: Pengantar dan teori. Malang: Salemba Medika

Niven, N. (2000). Psikologi kesehatan. (Edisi 3). Jakart: EGC

Notosoedirjo, M, L. (2002). Kesehatan mental konsep dan penerapan. Universitas Muhammadiyah Malang

Nursalam. (2008). Konsep dan penerapan metodologi penelitian ilmu keperawatan (edisi 2). Jakarta: Salemba Medika.

Prayitno, E. (2006). Psikologi orang dewasa. Padang: Angkasa Raya

Setiaji, S. (2002). Upaya yang perlu dilakukan untuk menghilangkan stigma masyarakat terhadap gangguan jiwa. Yogyakarta: Bagian Ilmu Kedokteran Jiwa Fakultas Kedokteran Jiwa UGM.

Setya, T. (2009). Pengaruh terapi aktifitas kelompok : sosialisasi terhadap kemampuan berinteraksi pada kien isolasi sosial di Rumah Sakit Jiwa Pusat Dr. Soeharto Heerdjan Jakarta. Diakses tanggal 4 Juni 2011 dari http://darsananursejiwa.blogspot.com/201 0/05/strategi-pelaksanaan-tindakan.html

Stuart, G. \& Laraia. (2005). Principles and practice of psychiatric nursing. Misouri: Mosby Year Book.

Stuart, G.W. \& Sundeen, S. J. (2006). Principles and practice of psychiatric nursing. Mosby Year Book : Misouri

Townsend, M.C. (2009). Psychiatric mental health nursing: Consepts of care in evidence-based practice. Philadelphia: FA. Davis.
Varcarolis \& Halter. (2010). Foundations of psychiatric mental health nursing: A clinical spproach, (Edisi 6). Philadelphia: WB. Saunders Company. 